\title{
Sistem Informasi Geografis Tempat Wisata Edukasi di DKI Jakarta
}

\section{Berbasis Android}

\author{
Denny Setia Putra ${ }^{1)}$ \\ * Universitas Trilogi \\ 1)Jurusan Teknik Informatika, Universitas Trilogi, Jakarta 12740, email: \\ dennysetiaputra27@gmail.com
}

\begin{abstract}
Abstrak
Jakarta merupakan salah satu tujuan pariwisata di Indonesia. Berbagai tempat wisata edukasi dapat ditemui di DKI Jakarta seperti Monas, TMII, Kebun Binatang Ragunan, Planetarium, dan lain-lain. Berbagai tempat tersebut sangat bermanfaat untuk menambah wawasan bagi para pengunjung. Umumnya pengunjung tempat wisata mencari informasi melalui internet dengan smartphone mereka. Banyak diantaranya yang membutuhkan informasi tentang tempat wisata edukasi di DKI Jakarta sebelum berkunjung. Penelitian ini nantinya akan dapat membantu masyarakat dalam mencari alamat dan lokasi geografis tempat wisata edukasi di DKI Jakarta. Dalam mengembangkan sistem informasi geogragis ini peneliti menggunakan bahasa pemrograman Java dan XML, dimana Java digunakan untuk membangun sistemnya dan XML digunakan untuk membangun user interface atau tampilan antar mukanya, sedangkan basis data yang digunakan yaitu MySQL. Metodologi pengembangan sistem yang digunakan adalah metodologi Waterfall. Aplikasi Sistem Informasi Geografis berbasis Android ini merupakan suatu aplikasi pembantu yang dapat diakses oleh user untuk mendapatkan informasi geografis tentang tempat wisata edukasi di DKI Jakarta. Dengan menggunakan sistem informasi geografis dengan bahasa pemograman Java dan MySQL dalam pengolahan data dan penyajian informasi, diharapkan dapat menghasilkan informasi yang lebih cepat, tepat waktu dan akurat dibanding dengan sistem yang lainnya.
\end{abstract}

Kata kunci: Sistem Informasi Geografis, Eclipse, Java, Android, Waterfall.

\begin{abstract}
Jakarta is one of the tourism destinations in Indonesia. Various educational attractions can be found in Jakarta such as Monas, TMII, Ragunan Zoo, Planetarium, and others. Various places are very useful to add insight for the visitors. Generally visitors to the sights seek information via the internet with their smartphones. Many of them need information about education places in Jakarta before visiting. This research will be able to help the community in finding address and geographical location of educational tourism in Jakarta. In developing this geographic information system, the researcher uses Java and XML programming language, where Java is used to build the system and XML is used to build user interface or interface between the face, while the data base used is MySQL. System development methodology used is Waterfall methodology. Application of Geographic Information System based on Android is a helper application that can be accessed by user to get geographical information about education place of education in DKI Jakarta. By using geographic information system with Java programming language and MySQL in data processing and presentation of information, expected to produce information more quickly, timely and accurate compared with other system.
\end{abstract}

Keywords: Geographic Information System, Eclipse, Java, Android, Waterfall.

\section{Pendahuluan}

Jakarta merupakan salah satu tujuan pariwisata di Indonesia. Berbagai tempat wisata edukasi dapat ditemui di DKI Jakarta seperti Monas, TMII, Kebun Binatang Ragunan, Planetarium, dll. Berbagai tempat tersebut sangat bermanfaat untuk menambah wawasan bagi para pengunjung. Umumnya pengunjung tempat wisata mencari informasi melalui internet dengan smartphone mereka.

Aplikasi Sistem Informasi Geografis saat ini tumbuh tidak hanya secara jumlah aplikasi namun juga bertambah dari jenis keragaman aplikasinya. Pengembangan aplikasi Sistem Informasi Geografis kedepannya mengarah kepada aplikasi berbasis andorid yang lebih dikenal dengan nama mobile SIG. 
Hal ini disebabkan karena pengembangan aplikasi di lingkungan jaringan telah menunjukan potensi yang besar dalam kaitannya dengan geo informasi. Sebagai contoh adalah adanya peta online sebuah kota dimana pengguna dapat dengan mudah mencari lokasi yang diinginkan secara online melalui jaringan internet tanpa mengenal batas geografi penggunanya.

Menyadari akan semua ini, timbul inisiatif untuk berpartisipasi aktif dalam membangun suatu aplikasi sistem informasi tempat wisata edukasi di DKI Jakarta berbasis android yang mempunyai pengunjung yang berasal dari dalam daerah DKI Jakarta, dari luar daerah bahkan wisatawan dari mancanegara. Wisatawan yang berkunjung ke tempat wisata edukasi DKI Jakarta ini mulai dari kalangan anak-anak, dewasa, sampai orang tua. Banyak diantaranya yang membutuhkan informasi tentang tempat wisata edukasi di DKI Jakarta sebelum berkunjung. Aplikasi sistem informasi ini memungkinkan para wisatawan untuk mengakses informasi secara realtime, tepat, akurat, dan terpercaya. Penelitian ini menerapkan aplikasi berbasis Android yang akan dibutuhkan oleh para wisatawan untuk mengetahui segala sesuatu tentang lokasi tempat-tempat wisata edukasi di DKI Jakarta dengan menggunakan Java sebagai bahasa pemrogramannya.

\section{Tinjauan Pustaka}

Dalam penelitian sebelumnya yang berjudul "Rancangan Bangun Sistem Informasi Geografi Berbasis Android Pemetaan Fasilitas Automated Teller Machine Menggunakan Google Maps Api Dan Metode Uji Produk ISO 9126" pada tahun 2017, Yosef Murya Kusuma Ardhana mengatakan bahwa berdasarkan uji produk Functionality, Reability, Usability dan Efficiency dengan nilai skor $>3.0$ maka sistem informasi geografis lokasi atau pemetaan dapat dikatakan dapat membantu pengguna dalam memberikan informasi tempat secara lengkap dan jelas yang dapat dilakukan dimanapun dan kapanpun dengan smartphone Android. Sistem informasi geografis dapat membantu pengguna dalam mendapatkan informasi lokasi secara efektif sehingga sistem menjadi sarana informasi yang dapat dilakukan dimanapun dan kapanpun oleh pengguna. Berdasarkan hasil dari uji sistem informasi geografis dengan metode pengujian functionality, reliability, usability dan efficiency yang terdapat pada ISO 9126, menunjukan bahwa sistem ini memberikan informasi tempat atau lokasi secara lengkap dan jelas dimanapun dan kapanpun.

Dalam penelitian lainnya pada tahun 2014 yang berjudul "Implementasi Sistem Informasi Geografis Daerah Pariwisata Kota Semarang Berbasis Android Dengan Global Positioning System (GPS)" Richard
R.F.S., dkk juga mengatakan Google Map API dan Google Places API merupakan komponen utama dalam Sistem Informasi Geografis. Global Positioning System berperan penting dalam menentukan keakuratan posisi dari pengguna. Sistem informasi geografis bermanfaat untuk mengetahui lokasi wisata, tempat ibadah, ATM, serta Bandara. Sistem informasi geografis berbasis Android dapat diakses oleh siapa saja tanpa perlu login. Sistem informasi geografis berbasis Android dapat digunakan dengan spesifikasi minimum sistem operasi Gingerbread.

Adapun penelitian lain oleh Farijz Milzan, dkk pada tahun 2016 yang berjudu "Sistem Informasi Geografis Tour Dan Travel Berbasis Android Di Kabupaten Tegal" dikatakan bahwa, Google Maps API merupakan komponen utama pada aplikasi Tracking Travel. Global Positioning System berperan penting dalam menentukan keakuratan posisi dari pengguna. Aplikasi Tracking Travel bersifat publik, didistribusikan untuk umum, dapat diakses oleh siapa saja tanpa harus login.

Penelitian oleh Indra Jati Kusuma pada tahun 2013 yang berjudul "Sistem Informasi Geografis Pariwisata Pulau Lombok Berbasis Android" dinyatakan bahwa penelitian ini berhasil membangun Sistem Informasi Geografis Pariwisata Berbasis Android yang menyediakan informasi lokasi wisata, alat transportasi yang dapat digunakan ke lokasi wisata, jarak wisatawan dari tempat wisata, dan fasilitas yang disediakan dilokasi wisata.

Jumadi, dkk (2009), menyatakan bahwa Sistem Informasi Geografis sangat bermanfaat untuk melaksanakan manajemen air tanah. Banyak fungsi manajerial dan pengambilan keputusan yang dapat dibantu menggunakan sistem ini, misalnya penerbitan rekomendasi maupun perijinan yang memungkinkan tersedianya informasi kewilayahan secara cepat menyangkut variable-variabel penting yang digunakan dalam upaya menjaga kelestarian air tanah. Bahkan dengan teknologi Java Applet, MySQL Spatial dan PHP memudahkan bagi pengembang untuk membuat pemodelan spatial maupun non spatial.

Menurut Ryana Frianto (2014), dalam bidang Sistem Informasi Geografis (SIG) atau Geographic Information System (GIS) yaitu teknologi yang menjadi alat bantu dan sangat esensial untuk menyimpan, memanipulasi, menganalisis, dan menampilkan kembali kondisikondisi alam dengan bantuan data atribut dan keruangan. Untuk mendapatkan informasi lokasi yang stategis perencanaan spasial sangatlah penting. Sistem Informasi Geografis (SIG) merupakan langkah yang dapat digunakan karena mempunyai kemampuan yang sangat luas baik dalam proses pemetaan maupun analisis. 


\section{Metode, Pembahasan dan Hasil}

\section{Model Waterfall}

Model waterfall memberikan sebuah pendekatan pengembangan sistem yang sistematik, dimulai pada fase perencanaan sistem, analisis, desain, kode, pengujian dan pemeliharaan.

\section{A. Perencanaan Atau Rekayasa Dan Pemodelan Sistem}

Pada fase ini dilakukan identifikasi sistem, studi kebutuhan pengguna, dan studi kelayakan sistem baik secara teknis maupun teknologi serta penjadwalan pengembangan sistem.

\section{B. Analisis Kebutuhan Perangkat Lunak}

Pada fase ini pengumpulan kebutuhan diidentifikasi dan difokuskan pada sistem yang akan dibangun meliputi identifikasi domain informasi, tingkah laku sistem, untuk kerja dan antar muka sistem. Kebutuhan untuk sistem didokumentasikan dan dikonsultasikan lagi bagi pengguna.

\section{Desain}

Fase ini difokuskan pada proses desain struktur data, arsitektur sistem, representasi interface dan algoritma program.

\section{Kode}

Setelah proses desain selesai maka hasilnya harus diterjemahkan ke dalam bentuk program komputer yang kemudian menghasilkan suatu sistem.

\section{E. Pengujian}

Pengujian dilakukan untuk menemukan kesalahan-kesalahan yang memungkinkan terjadi pada proses pengkodean serta memastikan bahwa input yang dibatasi memberikan hal yang sesuai dengan kebutuhan.

\section{F. Pemeliharaan Dan Pengoperasian}

Ditandai dengan penyerahan perangkat lunak kepada pemesannya untuk dioperasikan. Dalam masa operasional, perangkat lunak masih memungkinkan untuk terjadi sesuatu kesalahan atau kegagalan dalam menjalankan fungsi, perangkat lunak tersebut masih membutuhkan proses dari waktu ke waktu.

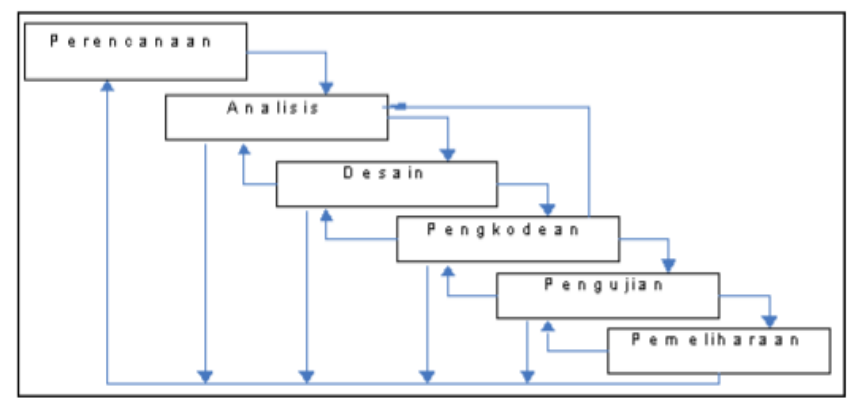

Gambar 1. Model Waterfall

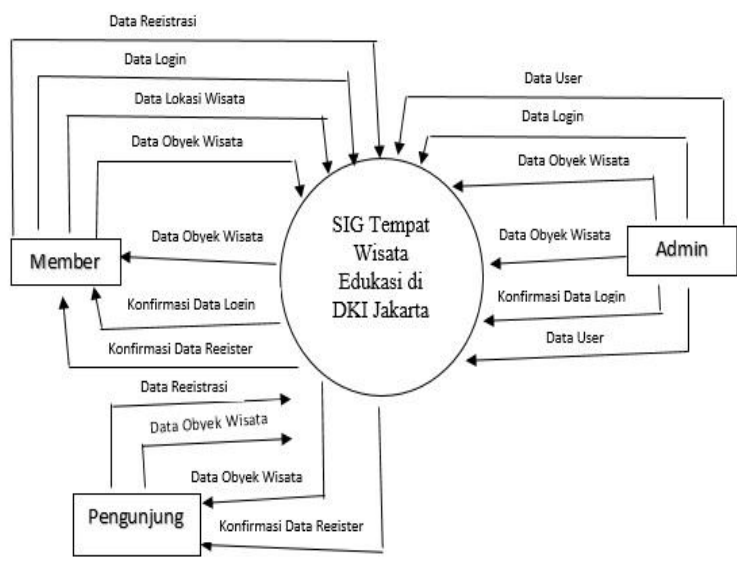

Gambar 2. Data Flow Diagram

Data Flow Diagram digunakan untuk mengetahui gambaran alur sistem data SIG dari admin, member, maupun pengunjung. Pengunjung sebagai pengguna system dan admin sebagai pengelola sistem Pada user terdapat beberapa alir data yaitu data obyek wisata, data registrasi, dan data login. Pada admin juga terdapat alir data yaitu data login, data user, data obyek wisata.

\section{ERD (Entity Relationship Diagram)}

Perancangan sistem ini menggunakan ERD sebagai dasar pembuatan tabel-tabel basis data pada sistem ini.

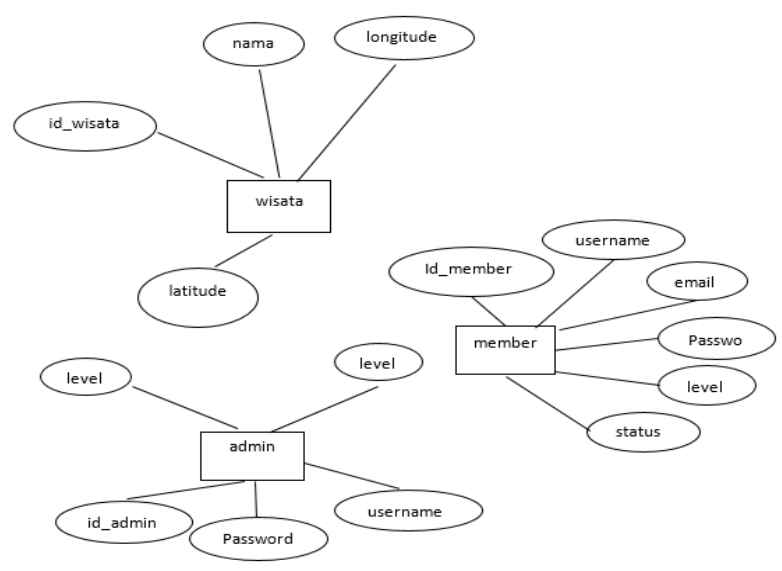

Gambar 3. Entity Relationship Diagram

Dalam sistem yang dibuat terdapat tabel wisata, tabel admin, tabel user:

\section{A. Tabel Admin}

Tabel basis data yang digunakan untuk menyimpan data admin seperti username dan password admin yang digunakan untuk keperluan login pada halaman utama aplikasi. 


\section{B. Tabel Wisata}

Tabel basis data yang digunakan untuk menyimpan data wisata yang bertujuan untuk menambah wisata yang ada pada halaman wisata.

\section{Tabel User}

Tabel basis data yang digunakan untuk menyimpan data user berisi username dan password untuk melakukan proses login. Sebelum melakukan proses login, user harus registrasi terlebih dahulu. Setelah registrasi, user akan diberikan link yang dikirim ke email. Setelah link diklik, maka status user menjadi aktif dan bisa melakukan proses login.

\section{Rancangan Masukan}

Perancangan masukan dalam perancangan aplikasi SIG (Sistem Informasi Geografis) Tempat Wisata Edukasi di DKI Jakarta Berbasis Android adalah:

\section{A. Input Data Peta}

Membuat layout untuk menampilkan peta yang berisi arah, lokasi, dan lain-lain. Perancang aplikasi membuat hanya menampilkan saja dan berisi gambaran lokasi.

\section{B. Input Data Tempat Wisata}

Perancang aplikasi menginput data tempat wisata yang ada di MySQL, tampilan berupa :

$\begin{array}{lll}\text { No } & : \text { (Nomor urut tempat } \\ \text { wisata) } & & \end{array}$

Nama Tempat Wisata : : (Nama tempat wisata yang akan diinput)

Deskripsi

: (Penjelasan data tempat

wisata)

Gambar

: (Berisikan url gambar data

tempat wisata)

\section{Rancangan Proses}

Rancangan proses SIG (Sistem Informasi Geografis) Tempat Wisata Edukasi di DKI Jakarta berbasis android ini menggunakan bahasa Java dan MySql yang sudah terintergrasi didalamnya. Program ini dirancang sebagai berikut:

A. User masuk kedalam aplikasi android yang sudah terinstal pada hp android, user akan menampilkan halaman menu utama.

B. Pada layout menu utama user akan dihadapkan menu-menu pilihan, seperti sejarah, cari, maps, dan, tentang. User dapat mengklik sesuai pilihan menu apabila sejarah maka akan beralih ke layout yang berisi sejarah tempat wisata.

\section{Rancangan Keluaran}

Perancangan keluaran (output) yang dimaksud adalah perancangan tampilan yang berupa tampilan antar muka (interface). Perancangan keluaran/output pada sistem management pembelajaran berbasis website terdiri dari:

\section{A. Layout Sejarah}

User dapat melihat informasi tentang sejarah tempat wisata dari awal berdiri hingga sekarang.

\section{B. Layout Cari}

User dapat mencari tempat yang akan dikunjungi berisikan informasi tempat wisata dan arah menuju tempat wisata tersebut.

Nama keluaran : Layout Cari

Tujuan : User

Isi $\quad$ : Info data tempat wisata

\section{Layout Maps}

User dapat melihat lokasi jika anda berada di tempat wisata yang berisikan informasi peta keseluruhan tempat.

\section{Layout Tentang}

User dapat melihat cara mengoperasikan aplikasi ini, tahun pembuatan aplikasi, pembuat aplikasi, dan lain-lain.

\section{Rancangan Layar}

\section{A. Layar Menu Utama}

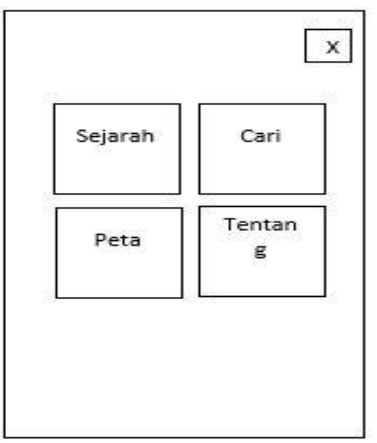

Gambar 4. Rancangan Layar Menu Utama

B. Layar Sejarah

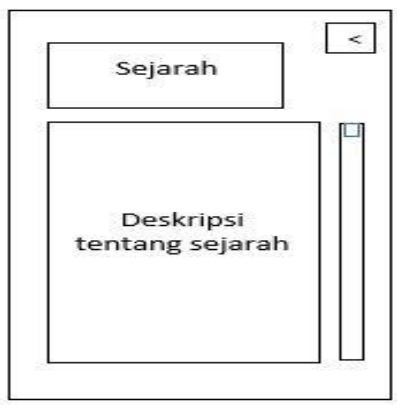

Gambar 5. Rancanga Layar Sejarah 
8. Tampilan Layar

\section{Layar Cari}

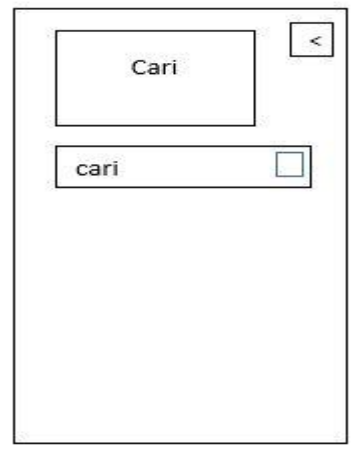

Gambar 6. Rancangan Layar Cari

D. Peta

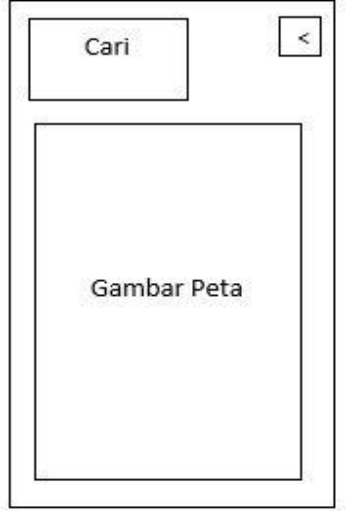

Gambar 7. Rancangan Layar Cari

E. Layar Tentang

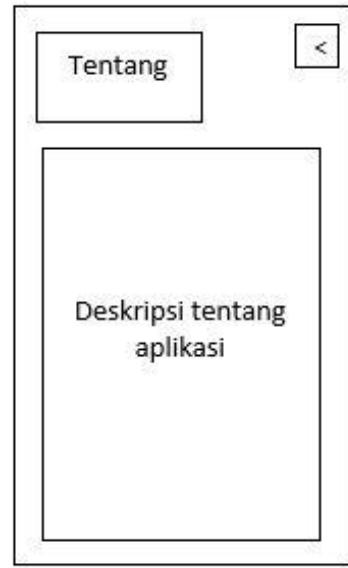

Gambar 8. Rancangan Layar Tentang
A. Layar Menu

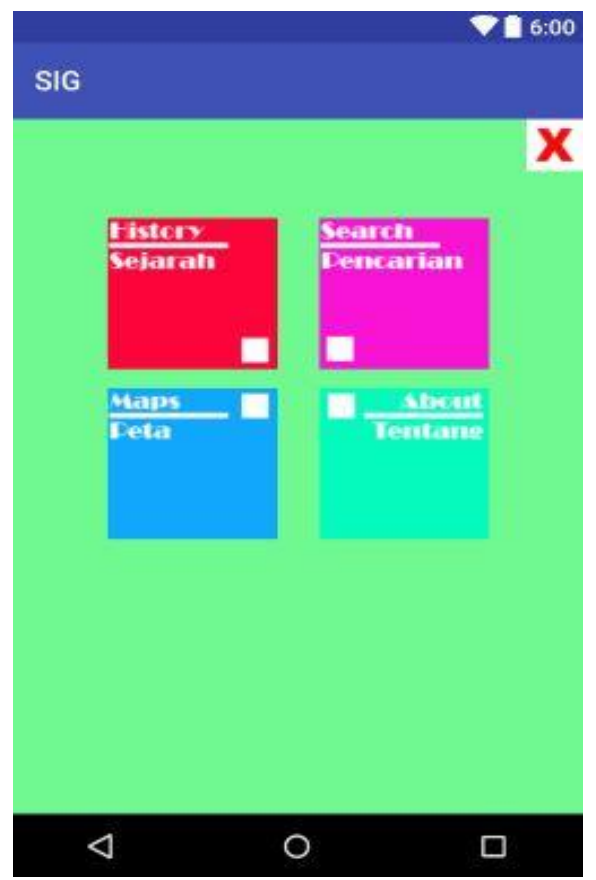

Gambar 9. Rancangan Layar Menu

Layar ini merupakan tampilan interface untuk memilih pilihan yang lain. Layar ini juga tampilan pertama saat menjalankan aplikasi android.

\section{B. Layar Menu Cari}

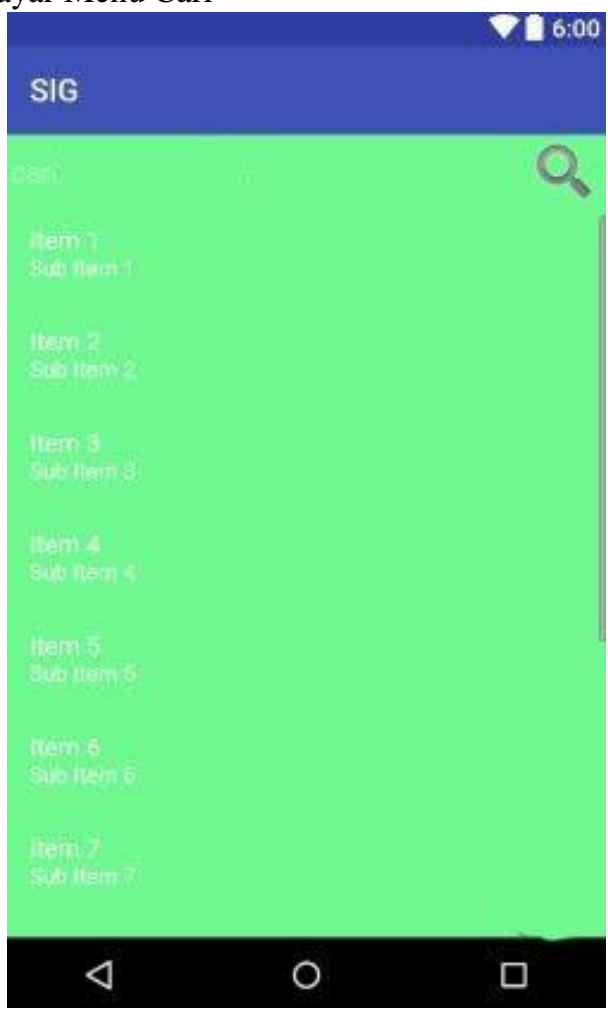

Gambar 10. Rancangan Layar Menu Cari 


\section{Kesimpulan}

Dari uraian dan proses pembuatan aplikasi Sistem Informasi Geografis ini, peneliti dapat menarik beberapa kesimpulan sebagai berikut:

1. Proses pengunjung mendapatkan info dari aplikasi yang penulis buat lebih cepat, tepat dan akurat dengan menggunakan aplikasi berbasis android, pengunjung dengan cepat dapat menemukan lokasi yang ingin ditujunya.

2. Pelayanan tempat wisata edukasi karena adanya aplikasi ini semakin baik, dapat diakses hanya dengan menginstalnya dan dengan mudah digunakan secara bebas.

3. Pengunjung lebih memahami aplikasi ini karena sangat simpel dan mudah digunakan tanpa harus bersusah payah dalam menggunakan aplikasi ini, tidak memerlukan tenaga yang besar, dan lebih user friendly (lebih bersahabat dengan penggunanya).

4. Proses dalam mendapatkan informasi di tempat wisata edukasi yang tadinya sulit dapat lebih mudah dengan sistem yang terkomputerisasi secara mobile sehingga lebih efektif dan efisien.

\section{Daftar Pustala}

[1] Ardhana Kusuma Murya Yosef, Rancang Bangun Sistem Informasi Geografi Berbasis Android Pemetaan Fasilitas Automated Teller Machine Menggunakan Google Maps Api Dan Metode Uji Produk ISO 9126, Yogyakarta: 2017.

[2] R. F. S. Richard, Satoto Kodrat Imam dan Martono Teguh Kurniawan, "Implementasi Sistem Informasi Geografis Daerah Pariwisata Kota Semarang Berbasis Android Dengan Global Positioning System (GPS)," Fakultas Teknik, Universitas Diponegoro, Semarang, Indonesia,2014.

[3] Milzan Farijz, Kridalukmana Rinta, Windasari Ike Pertiwi, "Sistem InformasiProgram Studi Sistem Komputer Fakultas Teknik Universitas Diponegoro, Semarang Indonesia, 2016.

[4] Kusuma Indra Jati, istem Informasi Geografis Pariwisata Pulau Lombok Berbasis Android, Fakultas Sains Dan Teknologi Universitas Islam Negeri Sunan Kalijaga, Yogyakarta, 2013.

[5] Jumadi dan Widiadi Sigit "Pengembangan Aplikasi Sistem Informasi Geografis (SIG) Berbasis Web Untuk Manajemen Pemanfaatan Air Tanah Menggunakan PHP, Java Dan MySQL Spatial (Studi Kasus Di Kabupaten Banyumas),"
Forum Geografi, Vol. 23, No. 2, Desember 2009: 123-138

[6] Frianto Ryana, "Aplikasi Sistem Informasi Geografis Berbasis WebGis Pemetaan Tempat Masjid Di Pangkalpinang," Teknk Informatika STMIK ATMA Luhur Pangkalpinang, 2014. 